\title{
Konseling Logoterapi Dalam Penetapan Tujuan Hidup Remaja Broken home
}

\section{Nurani Jayanti}

\author{
Sunan Kalijaga Yogyakarta
}

nuranijayanti@gmail.com

Submitted: 2019-03-17, revised: 2019-03-17, accepted: 2019-06-25

\begin{abstract}
This paper aims to reveal how logotherapy counseling in setting adolescent life goals is broken home, by having a meaningful life humans will find a directed life process, logotherapy counseling invites clients to understand the wisdom of each problem from the beginning of the counseling process. The method used is library research. It can be seen that with 4 steps logotherapy counseling is the stage of forming and fostering rapport, the stage of disclosure and assessment of problems, the stage of joint discussion, and the stages of evaluation and conclusion. The results obtained from the research data sources are that logotherapy counseling can help clients determine their life goals, clients who face fearsome difficulties or are in conditions that do not allow them to move and creativity are helped to find the meaning of their life in how they deal with these conditions and how his suffering. Logotherapy counseling teaches clients to see the positive value of suffering and provides an opportunity to feel grateful for the suffering and problems being experienced by the client.
\end{abstract}

Keywords: Logotherapy; Counseling; Life Purpose

\begin{abstract}
Abstrak: Tulisan ini bertujuan untuk mengungkapkan tentang bagaimana konseling logoterapi dalam menetapkan tujuan hidup remaja broken home, dengan memiliki hidup bermakna manusia akan mendapati proses kehidupan yang terarah, konseling logoterapi mengajak klien untuk memahami hikmah dari setiap permasalahan sejak awal proses konseling. Metode yang digunakan adalah penelitian kepustakaan (library reseacrh). Dapat diketahui bahwa dengan 4 langkah konseling logoterapi yaitu tahap pembentukan dan pembinaan rapport, tahap pengungkapan dan penjajagan masalah, tahap pembahasan bersama, dan tahap evaluasi dan penyimpulan. Hasil yang didapat dari sumber data penelitian yaitu bahwa konseling logoterapi dapat membantu klien dalam menetapkan tujuan hidupnya, klien yang menghadapi kesukaran menakutkan atau berada dalam kondisi yang tidak memungkinkannya beraktivitas dan berkreativitas dibantu untuk menemukan makna hidupnya dengan cara bagaimana ia menghadapi kondisi tersebut dan bagaimana ia mengatasi penderitaannya. Konseling logoterapi mengajarkan kepada klien untuk melihat nilai positif dari penderitaan dan memberikan kesempatan untuk merasa bersyukur terhadap penderitaan dan masalah yang sedang dialami oleh klien.
\end{abstract}

Kata kunci : Konseling Logoterapi; Tujuan Hidup

\section{Pendahuluan}

Manusia adalah makhluk hidup yang unik, yang dalam setiap kehidupannya selalu menarik untuk diperbincangkan, dari lahir hingga kematian selalu ada hal yang bisa dijadikan pembelajaran. Setiap manusia yang lahir pasti berkeinginan untuk mendapatkan hidup yang seperti diinginkan, hidup bahagia. Namun, kehidupan seorang manusia selalu mengalami lika-liku dalam perjalanannya, ada yang dalam hidupnya sukses mencapai tujuan hidup namun ada pula yang gagal. Ada yang merencanakan kehidupannya dengan baik dalam setiap tahap dan ada pula yang hanya mengikuti arus perkembangan zaman atau mengalir apa adanya. Tentu keduanya akan berbeda dalam menikmati setiap prosesnya.

Setiap manusia pasti mempunyai cita-cita dan tujuan hidup yang ingin dicapainya. Tujuan hidup itu akan diperjuangkan dengan semangat yang tinggi, segala kemampuan dikerahkan untuk mencapai tujuan hidup yang sesuai keinginannya, yang mana niat itu akan mengarahkan pada kegiatan sehari-hari. Ketika tujuan itu tercapai maka setiap individu akan merasakan sebuah kepuasan dalam hidupnya yang akhirnya dapat memberikan kebermanfaatan bukan hanya bagi dirinya tetapi juga untuk lingkungan sosialnya. Untuk mencapai sebuah kebermakanaan hidup ternyata tidaklah mudah. Setiap individu memiliki cara tersendiri dalam memaknai hidupnya, Bastaman menekankan bahwa cara yang lazim dilakukan orang-orang untuk menemukan makna hidupnya yaitu dengan beribadah. Ibadah 
ini merupakan perwujudan dari religiusitas manusia. Ibadah adalah segala kegiatan untuk melaksanakan perintah Tuhan, dan mencegah diri dari hal-hal yang dilarangNya. Kemudian Frankl merumuskan bahwa secara mendasar setiap situasi kehidupan atau kejadian-kejadian yang dialami oleh seseorang memiliki makna dan seseorang perlu menemukan makna tersebut karena makna adalah pencarian dan penemuan eksistensial seseorang(Sumanto, 2006).

Namun tak sedikit individu yang juga kehilangan makna hidupnya. Frankl mengobservasi bahwa kondisi kehilangan makna atau perasaan tanpa makna merupakan kondisi kevakuman eksistensial yang dapat membuat seseorang menjadi frustasi sehingga dapat mengarah kepada kondisi sakit bahkan yang terburuk pada kondisi kematian. Menurut Frankl (dalam Lathief, 2008), Yang paling dicari dan diinginkan manusia (individu) dalam kehidupan adalah makna, yaitu makna dari segala peristiwa yang dialami, terutama makna kehidupan individu itu sendiri. Keinginan akan makna (the will to meaning) adalah penggerak utama kepribadian manusia. Konsep keinginan terhadap makna ini merupakan tulang punggung teori kepribadian dan psikoterapi yang telah dikembangkan Frankl yakni Logoterapi(Ari Wibowo, 2016). Maksud utama dari logoterapi adalah untuk membantu klien dalam mencari makna hidup.

Penelitian yang berhubungan dengan logoterapi dan makna hidup sudah banyak dikemukakan, diantaranya adalah penelitian yang dilakukan oleh Vera Ukus, Hendro Bidjuni, dan Maikel Karundeng (2015) penelitian ini menekankan pada analisis pengaruh pemberian logoterapi terhadap kebermaknaan hidup pada lansia sebesar $16,5 \%$ dari $51,1 \%$ menjadi 67,6\%. Kemudian, menurut Sigit Ari Wibowo (2016) penelitian ini menekankan pada bagaimana penerapan konseling individu dengan teknik logoterapi mampu mempengaruhi kecenderungan perilaku mengalahkan diri (self defeating) pada siswa Sekolah Menengah Atas. Temuan pada penelitian ini yaitu dengan menggunakan taraf signifikan 5\% adalah 0,05 maka dapat disimpulakn bahwa harga $0,03<0,05$, maka ada penurunan kecenderungan perilaku mengalahkan diri (self defeating) pada siswa Sekolah Menengah Atas setelah pemberian konseling individu dengan teknik logoterapi.

Penelitian yang lain yang dilakukan oleh Hana Uswatun Hasanah dan Suprapto (2013) penelitian ini menekankan pada pengembalian makna hidup lansia yang telah hilang karena perubahan fisik dengan menggunakan konseling logoterapi dengan metode dereflection. Temuan pada penelitian ini menunjukkan bahwa konseling logoterapi dapat meningkatkan makna hidup pada lansia. Kemudian, penelitian yang dilakukan oleh Erwin Erlangga (2017) penelitian ini menekankan pada peningkatan penerimaan anak broken home sehingga mempunyai makna hidup. Temuan pada penelitian ini yakni terjadi peningkatan penerimaan anak broken home yakni sebesar 30,00\%, bahwa terapi kelompok dengan teknik logoterapi efektif untuk meningkatkan penerimaan anak broken home.

Berdasarkan penelitian terdahulu sebagaimana dikemukakan diatas, dapat dikatakan bahwa penelitian tentang logoterapi sudah banyak dilakukan namun belum ada yang secara spesifik membahas tentang konseling logoterapi dalam menetapkan tujuan hidup remaja broken home. Terlebih pada masa remaja mereka memiliki tugas perkembangan yaitu mencari identitas dirinya, akan sangat kebingungan ketika ia tidak mampu menyelesaikan tugas perkembangan tersebut sehingga yang terjadi ia akan kehilangan atau kebingungan akan jati dirinya sendiri. Dalam menyelesaikan tugas perkembangan setiap tahap dibutuhkan dorongan dari orang dan lingkungan disekelilingnya, dan salah satunya adalah orang tua. Namun akan beda hal nya ketika orang tua pun tak mampu menjadi faktor pendorong si anak dalam menyelesaikan tugas perkembangan tersebut, karena ternyata ketika masa remaja ia sudah harus mengalami rasanya masalah yang dihadapi oleh orang tuanya yaitu salah satu contohnya adalah broken home. Kemudian disinilah akan dipertanyakan, bagaimana peran dari konseling logoterapi dalam membantu menetapkan tujuan hidup remaja yang mengalami 
broken home? Langkah apa yang akan digunakan dalam membantu remaja tersebut? Dengan ini maka konselor akan membantu remaja dalam menetapkan tujuan hidupnya.

\section{Metode Penelitian}

Penelitian ini menggunakan penelitian kepustakaan (library reseach), disebut penelitian kepustakaan karena data-data atau bahan-bahan yang diperlukan dalam menyelesaikan penelitian tersebut berasal dari perpustakaan baik berupa buku, ensklopedi, kamus, jurnal, dokumen, majalah dan lain sebagainya(Khatibah, 2013).

\section{Hasil dan Pembahasan}

Tujuan Hidup

Manusia adalah makhluk (ciptaan) Tuhan, hakikat wujudnya bahwa manusia adalah makhluk yang perkembangannya dipengaruhi oleh pembawaan dan lingkungan. Manusia pada mulanya tidak ada kemudian ada, adanya manusia bukan ada dengan sendirinya, tetapi ada yang mengadakan, yang mengadakan atau menciptakan manusia adalah Allah SWT, Allah yang menciptakan manusia dengan segala kelengkapannya. Manusia keluar dari rahim ibunya hingga masuk kubur bukan hanya untuk bersenang-senang, tetapi disana ada perintah yang harus dilaksanakan, ada larangan yang harus dijauhi, dan ada peraturan yang harus ditaati(Sutoyo, 2014). Tujuan kehidupan manusia, yakni(Palindangan, 2013):

1. Untuk merealisasikan diri menjadi semakin sempurna dan utuh. Dengan kata lain kehidupan bagi manusia merupakan kesempatan baginya untuk semakin merealisasikan dirinya. Kesimpulan ini berangkat dari penyelidikan atas fakta bahwa manusia tidak pernah merasa hidupnya sudah sempurna. Sebaliknya ia mengalami dirinya selalu ditarik ke atas ke arah kesempurnaan, kebijaksanaan, keutamaan, kebaikan terus-menerus. Dengan kata lain manusia tidak pernah menerima dirinya sebagai sudah sempurna, sudah utuh sampai kehidupan itu sendiri dialaminya bertemu dengan kematian.

2. Untuk menjalani proses menuju hakikatnya. Kematian bagi manusia tidak diterima sebagai suatu yang wajar. Ketika seseorang menyadari kematian dirinya, atau orang yang dikasihinya, ia buru-buru mengusirnya dari kesadarannya, atau orang tidak mengusir dari kesadarannya tetapi membayangkannya dengan penuh ketakutan. Manusia menolak kematian, padahal kehidupan setiap orang dengan pasti maju secara perlahan menuju ke kematian.

Dalam sebuah perjalanan kehidupan tidak ada yang selamanya baik atau bahagia, pasti akan ada hal-hal buruk atau sedih dalam perjalannya. Seperti yang dikatakan oleh Leahy tidak ada apapun di dunia ini yang mampu untuk memenuhi hasrat manusia untuk mengalami kebahagiaan yang paripurna dan definitif(Palindangan, 2013). Karena kebahagiaan yang didapat oleh manusia akan senantiasa memudar dan hilang sehingga menuntut pemenuhan kebahagiaan kembali. Maka tujuan hidup yang dirindukan manusia adalah kehidupan bahagia yang paripurna atau menjadi manusia seutuhnya.

Menurut Prayitno, manusia seutuhnya itu adalah mereka yang mampu menciptakan dan memperoleh kesenangan dan kebahagiaan bagi dirinya sendiri dan bagi lingkungannya berkat pengembangan optimal segenap potensi yang ada pada dirinya (dimensi keindividualan), seiring dengan pengembangan suasana kebersamaan dengan lingkungan sosialnya (dimensi kesosialan), dan segala sesuatunya itu dikaitkan dengan pertanggungjawaban atas segenap aspek kehidupannya di dunia terhadap kehidupan di akhirat kelak kemudian hari (dimensi keagamaan). Kemudian menurut Frankl ciri-ciri manusia seutuhnya (berfungsi secara idela): 
1. Mencapai penghayatan yang penuh tentang makna hidup dan kehdidupannnya

2. Bebas memilih dalam bertindak

3. Bertangung jawab secara pribadi terhadap segala tindakan

4. Melibatkan diri dalam kehidupan bersama orang lain.

Setiap individu manusia pasti sangat ingin mempunyai makna dalam hidupnya, agar senantiasa dapat menjalani kehidupannya dengan terarah. Menurut Frankl, karena Keinginan terbesar manusia adalah berjuang untuk menemukan makna dalam hidupnya yang merupakan menjadi motivator utama dalam hidup manusia(Sumanto, 2006).

Menurut Bastaman ada lima metode yang digunakan dalam menunjukkan pentingnya menemukan dan menetapkan makna dan tujuan hidup yang jelas, yaitu:(Erfiana, 2013)

1. Pemahaman pribadi dan pengubahan sikap.

Manfaat dari metode ini adalah untuk mengenali keunggulan-keunggulan dan kelemahankelemahan pribadi, menyadari keinginan dari masa kecil hingga sekarang serta memahami kebutuhan-kebutuhan apa yang mendasari keinginan-keinginan itu, merumuskan secara lebih jelas dan nyata hal-hal yang diinginkan untuk masa mendatang serta menyusun rencana secara realistis untuk mencapainya.

2. Bertindak positif

Bertindak positif yaitu berusaha untuk menerapkan hal-hal yang baik dan positif dalam berperilaku dan tindakan nyata sehari-hari.

3. Pengakraban hubungan

Pengakraban hubungan yaitu berusaha untuk menjalin hubungan akrab seorang pribadi dengan pribadi yang lain sedemikian rupa sehingga dihayati sebagai hubungan yang dekat, mendalam, saling percaya dan saling memahami. Jadi terdapat semacam dukungan sosial. Seseorang dengan cara ini merasa dirinya berharga dan bermakna, baik bagi dirinya sendiri maupun bagi orang lain, karena hal ini merupakan salah satu sumber makna bagi manusia.

4. Pendalaman tri nilai.

Tri nilai di sini adalah pendalaman nilai-nilai kreatif yaitu dengan memberikan sesuatu yang berharga bagi kehidupan. Pendalaman nilai-nilai penghayatan, berkaitan dengan individu mencoba memahami, meyakini dan menghayati berbagai nilai yang ada dalam kehidupan, seperti keindahan, kebijakan, keimanan, kebajikan dan cinta kasih. Pendalaman nilai-nilai bersikap yakni memberi kesempatan kepada seseorang untuk mengambil sikap yang tepat terhadap kondisi dan peristiwa yang hadir dalam kehidupannya. Dengan mengambil sikap yang tepat maka beban pengalaman tragis akan berkurang, bahkan mungkin peristiwa itu dapat memberikan pengalaman yang berharga dan menimbulkan makna tertentu yang dalam sehari-hari disebut dengan hikmah.

5. Ibadah

Ibadah dalam pengertian umum adalah segala kegiatan untuk melaksanakan apa yang diperintahkan Tuhan dan mencegah diri dari hal-hal yang dilarang-Nya menurut ketentuan agama. Sedangkan dalam pengertian khusus ibadah adalah ritual untuk mendekatkan diri kepada Allah melalui cara yang diajarkan dalam agama.

Dengan kata lain bahwa individu yang mampu menerima setiap keadaan dalam kehidupannya kemudian menghadapinya dengan sikap positif dengan memaknainya sebagai sebuah hal yang selalu berputar, maka individu tersebut akan mampu mengendalikan rasa penderitaan yang berlebihan dalam menghadapi hal tersebut. Makna hidup dapat ditemukan dalam kehidupan itu sendiri, bagaimapun buruknya kehidupan tersebut. Makna hidup tidak hanya ditemukan pada kehidupan yang menyenangkan saja tetapi juga pada kehidupan yang menyedihkan, asalkan kita dapat mengambil hikmah dari setiap proses kehidupan maka kita dapat memaknai kehidupan tersebut.

Konseling Logoterapi 
Konseling adalah proses pemberian bantuan yang dilakukan melalui wawancara konseling oleh seorang ahli (konselor) kepada individu yang sedang mengalami sesuatu masalah (klien) yang bermuara pada teratasinya masalah yang dihadapi oleh klien(Prayitno \& Amti, 2009). Konseling merupakan sebuah kegiatan profesioanl, artinya kegiatan yang dilakukan bukan hanya berbincang-bincang tetapi dalam rangka membantu klien dalam menyelesaikan masalahnya. Sedangkan logoterapi dirintis dan dikembangkan oleh Viktor Frankl, secara singkat logoterapi berasal dari bahasa yunani, yaitu logos yang memiliki konotasi "makna" dan "jiwa". Manusia adalah makhluk pencari makna dan pencarian makna itu tidak patologis. Eksistensi menghadapkan orang pada kebutuhan untuk menemukan makna dalam hidupnya. Maksud utama logoterapi adalah untuk membantu klien dalam mencari makna. Maka dari itu usaha utama yang dilakukan konseling logoterapi adalah membantu klien dalam menyadari makna hidupnya dan dengan jalan itu menolong klien mengatasi masalah neurosis yang dialami(Triyono, 2018).

Logoterapi dalam proses konseling sama halnya dengan penggunaan pendekatan yang lain dalam menjajaki atau mengungkapkan, menafsirkan atau menganalisis, serta melakukan pembinaan atau penyelesaian serta melakukan penilaian atau evaluasi dari masalah klien. Namun dalam logoterapi lebih menekankan pada aspek pengarahan klien sejak tahap awal konseling untuk menemukan hikmah dari masalah yang dialami, tidak terlalu fokus pada asosiasi bebas, atau katarsis klien dalam menyampaikan masalahnya. Klien dalam pendekatan ini terlibat dalam pembukaan pintu diri. Pengalaman sering menakutkan atau menyenangkan dan mendepresikan atau gabungan dari semua perasaan tersebut. Dengan membuka pintu yang tertutup, klien mampu membuka belenggu deterministik yang menyebabkan klien terpenjara. Kemudian Frankl menekankan bahwa fungsi konselor bukanlah menyampaikan kepada klien apa makna hidup yang harus diciptakannya, melainkan mengungkapkan bahwa klien mampu menemukan makna, bahkan juga dari penderitaan, karena penderitaan bisa saja diubah menjadi prestasi melalui sikap yang diambilnya dalam menghadapi penderitaan itu.

Langkah-langkah dalam konseling logoterapi

Konseling logoteraphy berorientasi pada masa depan (future oriented) dan berorientasi pada makna hidup (meaning oriented) sebagai penetapan tujuan hidupnya. Relasi yang dibangun antara konselor dengan kelien adalah encounter, yaitu hubungan antar pribadi yang ditandai oleh keakraban dan keterbukaan, serta sikap dan kesediaan untuk saling menghargai, memahami dan menerima sepenuhnya satu sama lain. Ada empat tahap utama didalam proses konseling logterapi

yaitu:

1. Tahap perkenalan dan pembinaan rapor atau pembentukan suasana emosional yang nyaman antara konselor dengan klien. Pada tahap ini diciptakan suasana nyaman untuk konseling dengan pembina rapport yang makin lama membuka peluang untuk sebuah encounter. Inti dari encounter adalah penghargaan kepada sesama manusia, ketulusan hati, dan pelayanan.

2. Tahap pengungkapan dan penjajakan masalah. Pada tahap ini konselor mulai membuka wawancara konseling dengan klien, mengenai masalah yang dihadapi klien. Dalam logoterapi klien sejak awal diarahkan untuk menghadapi masalah itu sebagai kenyataan. Konselor mencoba menggali masalah yang dihadapinya, karena masalah pada remaja ini adalah broken home maka konselor akan menggali bagaimana kasus perceraian ini menjadi masalah bagi dirinya dan mengakibatkan dirinya hampir kehilangan tujuan hidup karena orang yang disayanginya harus berpisah. Dan tak lupa konselor mengambil peran dalam menyadarkan klien bahwa setiap manusia pasti memiliki masalah-masalah dalam hidupnya dan perantara masalah itu kita dibimbing menjadi manusia kuat dan mampu mengambil keputusan 
atau tindakan, dengan jalan menerima kenyataan kemudian menghadapinya adalah sebuah jalan terbaik dalam menyelesaikan sebuah permasalahan hidup.

3. Pada tahap pembahasan bersama, konselor dan klien bersama-sama membahas dan menyamakan persepsi atas masalah yang dihadapi. Tujuannya untuk menemukan arti hidup sekalipun dalam penderitaan.

Karena dalam konseling logoterapi ini klien diajak untuk menghadapi sebuah masalah sebagai sebuah kenyataan maka ini menjadi titik tolak untuk konselor membantu klien dan karena tahap penyadaran ini berada pada tahap kedua maka pada tahap ketiga ini dengan menyamakan persepsi antara konselor dan klien akan menjadi langkah awal dalam menghadapi dan menyelesaikan masalah klien yang merasa hampir kehilangan tujuan hidupnya akibat kasus perceraian kedua orang tuanya. Kemudian konselor membantu klien untuk terus bangkit dan tetap pada pandangan awal bahwa dengan kasus broken home ini bukan berarti kasih sayang kedua orang tua atas dirinya hilanag tetapai hanya sedikit berkurang dan ia masih bisa tetap berkumpul meski tak intens seperti dulu. Dengan berbagai penyamaan persepsi antara konselor dan klien ini akan menjadikan klien sadar bahwa meski dalam suasana penderitaan sekalipun kita sebagai manusia akan tetap mendapatkan apa arti hidup dari setiap masalah yang kita hadapi. Dengan ini maka konselor mengajak klien untuk mencari arti dari masalah yang dihadapinya saat ini dan juga tetap fokus pada apa yang harus dikerjakan atau dilakukan pada kehidupan selanjutnya. Pada tahap ini juga konselor akan membantu klien dalam menetapkan tujuan hidupnya ketika klien merasa bahwa sebauh masalah adalah sebuah hal yang wajar yang harus diterima dan diambil pelajaran didalamnya sehingga meski ia merasa masalah sebuah penderitaan ia mampu bangkit dan kemudian menentukan tujuan hidup kedepan dengan kondisi yang tak lagi sama seperti dahulu.

4. Tahap evaluasi dan penyimpulan mencoba memberi interpretasi atas informasi yang diperoleh sebagai bahan untuk tahap selanjutnya, yaitu perubahan sikap dan perilaku klien. Pada tahap-tahap ini terjadi modifikasi sikap, orientasi terhadap makna hidup, penemuan dan pemenuhan makna, dan pengurangan symptom. Setelah dilakukan proses konseling logoterapi beberapakali pertemuan maka langkah selanjutnya adalah evaluasi dan penyimpulan yang akan memberikan interpretasi bagaimana kondisi klien setelah melakukan proses konseling ataukah ada perubahan atau masih sama seperti pada awal pertemuan proses konseling. Tahap ini termasuk tahap yang cukup penting karena dengan ini konselor bisa mengambil tindakan selanjutnya apakah proses konseling akan berlanjut atau selesai. Ketika klien merasa bahwa ada perubahan dalam dirinya dan juga konsleor merasakan ada perubahan yang signifikan dalam diri klien maka selanjutnya konselor akan meyakinkan bahwa dalam setiap individu memiliki berbagai masalah dan masalah itu adalah hal yang wajar dalam hidup, bahkan dengan adanya masalah manusia bisa mengambil hikmahnya dan juga kita bisa terus melangkah maju kedepan.

\section{Simpulan dan Saran}

Dengan berbagai uraian diatas bahwa konseling logoterapi bertujuan untuk membangkitkan kemauan untuk bermakna dalam diri klien sehingga konseling logoterapi dapat membantu klien dalam menetapkan tujuan hidupnya. Dengan logoterapi, klien yang menghadapi kesukaran menakutkan atau berada dalam kondisi yang tidak memungkinkannya beraktivitas dan berkreativitas dibantu untuk menemukan makna hidupnya dengan cara bagaimana ia menghadapi kondisi tersebut dan bagaimana ia mengatasi penderitaannya. klien dibantu untuk menggunakan ketidaknyamannya dan penderitaannya sehari-hari sebagai alat untuk menemukan tujuan hidupnya. Kenyataan kita saat ini meyakinkan banyak orang untuk 
melihat penderitaan sebagai satu 'takdir' yang tidak dapat dicegah dan dielakkan. Akan tetapi logoterapi mengajarkan kepada klien untuk melihat nilai positif dari penderitaan dan memberikan kesempatan untuk merasa bersyukur terhadap penderitaan dan masalah yang sedang dialami oleh klien.

\section{Daftar Pustaka}

Ari Wibowo, S. (2016). Penerapan Konseling Individu dengan Teknik Logoterapi untuk Menurunkan Self Defeating pada Siswa Sekolah Menengah Atas. Jurnal BK UNESA, $6(1)$.

Erfiana, L. R. (2013). Hubungan antara Kebermaknaan Hidup dengan Kemandirian pada Remaja. EMPATHY Jurnal Fakultas Psikologi, 2(1).

Khatibah, K. (2013). Pengembangan Perpustakaan Sebagai Pusat Sumber Belajar dalam Kegiatan Instruksional pada IAIN-SU Medan. Iqra': Jurnal Perpustakaan Dan Informasi, 5(01), 36-39. Retrieved from http://repository.uinsu.ac.id/640/

Palindangan, L. K. (2013). Tinjauan Filosofis Tentang Hidup, Tujuan Hidup, Kejahatan, Takdir, dan Perjuangan. Jurnal Ilmiah Widya.

Prayitno, \& Amti, E. (2009). Dasar-Dasar Bimbingan dan Konseling. Jakarta: Rineka Cipta.

Sumanto. (2006). Kajian Psikologis Kebermaknaan Hidup. Buletin Psikologi, 14(2), 155135.

Sutoyo, A. (2014). Bimbingan \& Konseling Islam. Yogyakarta: Pustaka Pelajar.

Triyono, Y. (2018). Konseling Eksistensial: Suatu Proses Menemukan Makna Hidup. Jurnal Orientasi Baru, 19(1), 65-80. 
